\title{
The Perils of Repressive Tolerance in Music Education Curriculum
}

\author{
William M. Perrine \\ Concordia University Ann Arbor
}

In recent years, philosophers of music education have called for a greater degree of political engagement by music education practitioners. Using Marcuse's discussion of "repressive tolerance" as a conceptual framework, I argue that a politicized curriculum in music education works against the liberal ideas of free speech and a free marketplace of ideas, both of which are foundational to democratic society. In particular, when dissenting positions are repressed or misrepresented in a drive towards liberation, Critical Theory moves inappropriately into the realm of ideology. The application of Critical Theory to music education curriculum is critiqued in two areas: the danger of working within a closed theoretical system, and the discourse surrounding the large ensemble. I conclude by arguing that a degree of detachment from the political is, in fact, a virtue rather than a problem for music educators, and that this attitude should be commended rather than deconstructed.

Keywords: Music education, Marcuse, tolerance, curriculum, social justice

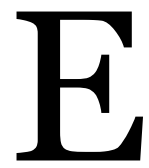

ducation, according to critical axiom, is an intrinsically political endeavor. In a free society, a variety of political perspectives on how to best advance the common good through formal education is to be expected. Within the field of curriculum theory, however, Critical Theory and its philosophical relatives have dominated discourse for several decades. Proponents of various strands of Critical Theory aim to liberate students from a pre-defined false consciousness towards specific political ends, namely the transformation of capitalist society and the development of "authentic" consciousness. In their critique of the status quo, theorists often preclude the viability of traditional perspectives, mistakenly assuming that the status quo is conservative in a meaningful philosophical sense. Yet, it is by no means entirely demonstrable that genuinely conservative ideas find actual

(C) William M. Perrine 2017. The content of this article is the sole responsibility of the author. The ACT Journal and the Mayday Group are not liable for any legal actions that may arise involving the article's content, including, but not limited to, copyright infringement. 
realization within the modern administrative state of which the public schools are an extension. Within this context the overgeneralization and oversimplification of conservative or libertarian perspectives within curricular inquiry for polemic purposes is both unsurprising and unfortunate. I am concerned that the misrepresentation of conservative viewpoints, and the attendant failure to consider all perspectives, obscures areas of mutual interest despite divergent philosophical bases and makes cooperative action across partisan lines to address areas of pressing social concern substantially less viable. Further, when applied in the classroom as a pedagogical approach, I will argue that Critical Theory tends to work against the values of free debate and student agency by delegitimizing conservative or libertarian perspectives in advance.

In this paper, I will provide evidence that these problems may be compounded when scholars in music education apply the analytical frameworks developed in curriculum theory to our own discipline. The rationale for proceeding along these lines at first appears self-evident: music in tertiary education tends to follow the conservatory model. The nature of the conservatory is to conserve, whether it be repertoire, pedagogical methods, or traditional ensembles. Because Critical Theory tends to conflate the terms conservative and regressive, the discourse tends to become not only political but moral as well; the regressive, after all, works in opposition to the liberatory. In practice, however, conservativism in one domain, such as music performance, does not necessitate conservativism in another, such as political sympathies. The false equivalency between various conservative practices can only be sustained by additional misrepresentation or oversimplification of the social or political import of traditional music education practices. This approach may prove to be destructive in the long run to music education as a profession. The bonds of voluntary association fostered by traditional ensembles, often supported by individuals of all political persuasions, are at risk in efforts to redefine or reconstruct music curricula for socio-political purposes.

Herbert Marcuse's concept of "liberating tolerance" provides an extraordinarily useful lens with which to examine this set of problems. Essentially, liberating tolerance denies space within social discourse for particular points of view deemed dangerously regressive. While Marcuse's views on education are perhaps cited less frequently than other Critical Theorists or Marxist humanists, his involvement

Perrine, William M. 2017. The perils of repressive tolerance in music education curriculum. Action, Criticism, and Theory for Music Education 16 (2): 6-38. doi:10.22176/act16.2.6 
with the student movement of 1960s generated long-term influence on the academy as his views on repressive tolerance framed discussion of ideological conflict and revolutionary praxis. Inasmuch as Marcuse's ideas have been absorbed as part of the ethos of the contemporary university, they are destructive towards classically liberal approaches to free inquiry and critical reflection. I will argue in this paper that the most appropriate philosophical and pedagogical response to the problems generated by approaching curriculum as critical politics is to reject liberating tolerance and embrace consensual tolerance as a civic virtue. Students are not means to liberatory ends, should be exposed to a diversity of thought in all disciplines authentically representative of its proponents, including music, and should be free to draw their own conclusions.

I will first summarize Marcuse's philosophy of tolerance, situating his conclusions within the larger framework of Critical Theory. From this discussion, I will offer a critique Marcuse's work, arguing that liberating tolerance tends towards ideological fanaticism due to its comprehensive and single-minded approach. I will next examine the ways in which liberating tolerance informs curriculum theory more broadly, noting particular areas of conceptual overlap with Critical Pedagogy and the work of Paulo Freire, before moving into a discussion of how liberating tolerance functions within current philosophical discussions in the field of music education. I will examine two areas in which scholarship in music education demonstrates symptoms of liberating tolerance: the misrepresentation of conservative viewpoints on curriculum theory, and philosophical discourse on the role of the large instrumental ensemble in the music curriculum. I argue that this approach is not beneficial to the profession, and that music educators should treat philosophical opponents with generosity and understanding grounded in divergent terms of discussion. While I am pessimistic regarding the possibilities of pure tolerance in the academy, I conclude that consensual tolerance remains the strongest approach to a vibrant debate and diverse educational praxis within a democratic society.

\section{Marcuse's Repressive Tolerance}

Herbert Marcuse's philosophical work tends to examine the negative impact of mass culture on the potential for liberatory action in capitalist democratic societies. His work as a member of the Frankfurt School of Critical Theory focused on

Perrine, William M. 2017. The perils of repressive tolerance in music education curriculum. Action, Criticism, and Theory for Music Education 16 (2): 6-38. doi:10.22176/act16.2.6 
the inability of the working class to initiate revolutionary action within late capitalism, and the manner in which sexual repression contributes to political oppression. Marcuse's influence in the United States primarily revolves around his influence on the student movements of the 1960s and 1970s. His essay on Repressive Tolerance (1965) sits within both the broader themes of his philosophical work and his interactions with the student movement. The essay made a lasting impact on how tolerance is understood within the academy, even when not referenced directly. The central premise of Marcuse's essay is that consumerism and capitalism have altered the function of tolerance to the point at which political tolerance actually serves a repressive function, protecting interests vested in the status quo and circumscribing the possibility of liberating revolutionary action.

Marcuse's argument begins with an analysis of the function of tolerance within democratic societies. Traditionally, the purpose of tolerance has been to provide balance between competing interests with the intent of preserving social harmony via liberty. The law protects the open expression of diverse viewpoints in a free marketplace of ideas; all voices have an equal right to be heard. This abstract ideal is "pure" tolerance, which extends to all sides of the political spectrum. Marcuse critiques pure tolerance on three fronts. First, he argues that the value of pure tolerance is dependent on the prevalence of equality within the broader society. Institutional inequality robs the poor and the oppressed of a voice within the marketplace of ideas, and essentially rigs the political game in favor of those with the financial means to make their voices heard. Second, traditional liberalism, and the tolerance it espouses, assumes that individuals are able to evaluate divergent viewpoints apart from established authority, independently drawing informed conclusions from the available facts. Within our affluent society, however, the majority is preoccupied with the satisfaction of consumer needs. Combined with a lack of access to authentic information, the result is indoctrination by mass culture. Individuals thus lack the rational basis to engage in informed discussion. Third, the marketplace of ideas gives false or even dangerous opinions equal weight in public discourse. As Marcuse puts it, "the stupid opinion is treated with the same respect as the intelligent one, [as] nobody, neither group nor individual, is in possession of the truth and is capable of determining what is right or wrong." The democratic process thus subverts rational inquiry leading towards truth, treating all truth claims as opinions in search of social consensus.

Perrine, William M. 2017. The perils of repressive tolerance in music education curriculum. Action, Criticism, and Theory for Music Education 16 (2): 6-38. doi:10.22176/act16.2.6 
Given the problematic nature of pure tolerance, Marcuse's argues that if the function of tolerance in a democratic society is primarily geared toward protecting political rights and liberties in an indiscriminate manner, pure tolerance is in fact repressive as it prevents the possibility for radical change. While even the most radical and reactionary movements have the freedom to speak, a constitutional democracy by its nature places limitations on the rights of the opposition. Principally, these limitations stipulate that dissenters maintain a right to free speech and assembly only if they do not move from thought to deed. Society tolerates subversion in the marketplace of ideas with the understanding that some good might come out of it...but only if subversives play by the rules of tolerance set in advance. Marcuse argues that this state of affairs renders minorities harmless and without recourse when confronted by entrenched majoritarian social structures. In particular, the oppressed are expected to tolerate their oppression, as the democratic system invariably favors majority interests at the expense of the exploited. The means to revolutionary action and liberation, including violence against oppression, remain unavailable.

Marcuse is careful to note that pure tolerance is indispensable in what he describes as the "private sphere": academic discussions, private religion, or even scientific investigation. In the public sphere, however, he argues that tolerance cannot and should not be extended to false ideas or harmful actions that impede the possibility of liberation. These include things such as indoctrination through propaganda, the recruitment of special forces for the military, deceptive merchandizing, planned obsolescence, and even aggressive driving. Marcuse further argues that we should refuse to tolerate those things that block revolutionary dissent, particularly the status quo supported by the concentration of economic and political power by a small elite in a capitalist society. While he recognizes that pure tolerance is superior to institutionalized intolerance, Marcuse's primary interest is in developing an alternative.

This alternative is what Marcuse describes as "liberating" or discriminating tolerance. The purpose of this type of tolerance is the discovery of truth. In this context, truth is a matter of what moves the society towards liberation, in which individuals can function autonomously, and are freed from a struggle for existence in a manner that does not involve oppression or exploitation. Liberating tolerance

Perrine, William M. 2017. The perils of repressive tolerance in music education curriculum. Action, Criticism, and Theory for Music Education 16 (2): 6-38. doi:10.22176/act16.2.6 
necessitates utilizing apparently undemocratic means in order to create room for effective subversion of prevailing societal structures:

Liberating tolerance, then, would mean intolerance against movements from the Right, and toleration of movements from the Left ... it would extend to the stage of action as well as of discussion and propaganda, of deed as well as word.

Specifically, Marcuse suggests withdrawing the rights of speech and assembly in the face of extreme danger to society or social progress. This includes not only those who discriminate on the basis of gender, race, or religion; it also involves withdrawing tolerance from those advocating aggressive policies or questioning the extension of government services such as health care or social security. Promotion of progressive policies necessitates the suppression of regressive ones. Marcuse justifies the imposition of an arguably illiberal approach by pointing to a perceived imbalance in public speech. Conservative and capitalist interests control the mass media, which shapes public thought, and the radical Left lacks purchasing power to promote its ideas on an even playing field. ${ }^{1}$ The solution to this inequity is thus to "restrain the liberty of the Right." From this standpoint, when the Right expresses regressive values it does not even represent a legitimate point of view except in a formalistic sense. Allowing the tolerance of regressive values enables their perpetuation and undermines the potential for liberatory action.

Marcuse's approach to understanding tolerance is grounded in the language and ideas of Critical Theory as a whole. While there are variations in philosophical approach and emphasis among various members of the Frankfurt School, common threads in Critical Theory include a neo-Marxist conceptual framework, in which insights from all branches of the social sciences are brought to bear on the problems of capitalist societies. From this perspective, the majority of individuals, even in a democratic society, exist in a state of alienation. Philosophy and social action are directed towards empowerment and liberation from the false consciousness perpetuated by late capitalism. Through liberation, individuals become autonomous beings capable of controlling the material forces of history, freed from oppression. A pronounced utopian streak runs through Marcuse's work, arguing for a society that does not yet exist, in which cruelty, competition, and exploitation no longer hold sway. Within the framework of Critical Theory, Marcuse's concept of

Perrine, William M. 2017. The perils of repressive tolerance in music education curriculum. Action, Criticism, and Theory for Music Education 16 (2): 6-38. doi:10.22176/act16.2.6 
liberating tolerance serves as a catalyst for actualizing his philosophical ideas. Liberating tolerance becomes a tool by which social space is created for revolutionary action and social progress.

Marcuse recognizes in his essay the impossibility of the state acting to implement liberating tolerance, as such action would subvert the structure of the democratic state itself. For a solution, he turns to educational institutions. Marcuse argues that the intelligentsia is in the best position to separate truth from falsehood, and thus determine which ideas are regressive enough to impede social progress. The freedom of thought Marcuse associates with liberating tolerance would "necessitate new and rigid restrictions on teaching practices in educational institutions," as traditional pedagogical approaches perpetuate false consciousness via the illusion of neutrality. Such an approach would provide an avenue of influence in an arena for which liberating tolerance would be a gatekeeper, namely providing alternatives to the established meaning of words and ideas. Marcuse does not suggest that an outside power or agency would be responsible for enforcing liberating tolerance against the Right; rather the solution, beginning in academia, would involve self-imposed pressures for revolutionary change. These pressures would be self-enforced by teachers and students. Various facets of university life that might appear curious from the outside have been criticized as realizations of Marcuse's approach (Kors and Silverglate 1999). These include both formal and informal speech codes, the angry interruption and harassment of conservative guest lecturers on campus, and the dis-invitation of controversial speakers from commencement ceremonies.

\section{Problems of Liberating Tolerance}

As a tool for advancing Critical Theory, liberation, or revolutionary action within an educational context, liberating tolerance in fact acts in a regressive manner, unnecessarily stunting the intellectual and moral growth of students and potentially denying their individual agency for social action. This criticism in itself does not necessitate a refutation of any of the central tenants of Critical Theory, although I would argue that such a project would have intrinsic value. Marcuse's presentation

of "liberating tolerance" commits two significant philosophical errors. First, Marcuse does not allow for the fallibility of his position. This occurs in a number of ways, most notably in his a priori commitment to neo-Marxist analysis as a true

Perrine, William M. 2017. The perils of repressive tolerance in music education curriculum. Action, Criticism, and Theory for Music Education 16 (2): 6-38. doi:10.22176/act16.2.6 
portrait of reality rather than as one philosophical position among many. Critics in the past have pointed out this weakness in his argument. For example, De Vitis (1974) argued that Marcuse is simply recycling and updating Platonic ideas on the nature and purpose of education. In setting himself and his peers up as de-facto philosopher kings within the context of the university, Marcuse bypasses the question of what or who gives him the right to liberate the minds of the young in his own image, beyond his unquestionable assertion of the inherent correctness of his political views. The argument for liberating tolerance thus rests on the ability of the intelligentsia to distinguish sociological fact from propaganda, and repress regressive ideas accordingly. Note, however, that Marcuse rigs the philosophical game in his own favor by denying the right of the "other side" to hold an opinion. The attempt to delegitimize dissent in reality weakens Marcuse's own position by failing to recognize a right to critique liberatory values. Liberating tolerance, by Marcuse's own definition, represses dissent. Second, like other Marxist humanists, Marcuse's use of language creates an unnecessary binary distinction between the oppressed and oppressors, in which social progress becomes a zero sum game in which individuals are either "with us or against us." Critics have also frequently noted the dualistic nature of this distinction (Fopp 2007; Scruton 2015). Those who might dare to disagree with various aspects of the liberatory narrative are with the oppressors; they suffer from false consciousness, enable the status quo, or hold regressive values. Characterizing opposition in this manner is merely an intellectualized version of an ad hominem attack, in which the attack is not on the individual per se, but rather on the individual's agency in holding heterodox opinions.

I would further argue that liberating tolerance's stated purpose, which is to repress speech that protects the status quo, in conjunction with its lack of fallibility and its aim of liberation, moves Marcuse's argument from the realm of philosophy into the realm of ideology. When ideology demands total commitment to an existing program of thought, it is in danger of slipping into fanaticism. David Blacker (1998) succinctly defines two primary characteristics of fanaticism: comprehensiveness and single-mindedness. While Blacker's argument aims primarily at religious fanaticism, he does note that his definitions apply equally well within a secular context. A viewpoint is comprehensive when it provides explanatory power for all phenomena within a believer's life. For the true believer in either a religion or an ideology, failure to achieve comprehensive application of the idea to all areas of

Perrine, William M. 2017. The perils of repressive tolerance in music education curriculum. Action, Criticism, and Theory for Music Education 16 (2): 6-38. doi:10.22176/act16.2.6 
life, in both thought and deed, amounts to hypocrisy. From a secular perspective, Blacker notes that Kant, Mill, and Dewey's approaches to autonomy, freedom, and growth are, respectively, comprehensive. Dewey, for example, argues that growth should be characteristic of all areas of life. A comprehensive viewpoint, however, is not necessarily fanatical if it does not meet the criteria of single-mindedness. Because the concept of fallibility is built into Dewey's conception of growth, Blacker reasons that it does not "fixate narrowly on some circumscribed doctrine, object, or ideal," his definition of single-mindedness. The implication of Blacker's argument is that the point at which a belief becomes single-minded is the point at which comprehensiveness rules out fallibility. A single-minded approach does not necessarily point to agreement of all areas of importance, but rather towards fixation on a particular core orthodoxy, whether well-defined or implicit. While it is likely uncontroversial to suggest that Critical Theory is comprehensive in its approach to understanding society, a fixation on liberation can become singleminded. The use of liberating tolerance to suppress dissent thus invokes infallibility through its suppression of dissent from orthodox positions, and crosses the line into fanaticism.

That this is so can be seen by further considering Blacker's criteria for identifying existing fanaticisms. These include proselytization, semantic policing, steep instrumentality, and determinate fixation. Blacker defines proselytization as "the desire to win converts or to reproduce the views of one's group." Proselytization by itself does not indicate fanaticism, as it is a general feature of group dynamics. The problem arises when members of a group seek "external comprehensiveness" through control of the educational process, working to reshape society as a totality. The concept of liberation in this context is a proselytizing device, designed to convert individuals enslaved by false consciousness to a predetermined conception of autonomy and freedom. Liberating tolerance also meets the criteria of semantic policing, which Blacker defines as the monitoring of speech patterns, a lack of external self-correcting mechanisms, and a marginalization of dissenting viewpoints in service of the ideology's comprehensive nature. In fact, Marcuse celebrates semantic policing as a tool for identifying and repressing regressive ideas; his approach to liberating tolerance is nearly synonymous with Blacker's semantic policing. Marcuse also engages in steep instrumentality, which Blacker defines as an "inability to appreciate a heterogeneity of value commitments," by refusing to

Perrine, William M. 2017. The perils of repressive tolerance in music education curriculum. Action, Criticism, and Theory for Music Education 16 (2): 6-38. doi:10.22176/act16.2.6 
acknowledge the validity of diverse opinions, even on matters such as state-provided welfare or health care. Steep instrumentality instrumentalizes all beliefs and actions in service of the ideology's overarching goals, admitting their value only in relation to specified ends. Finally, the extent to which liberating tolerance displays determinate fixation is more debatable. Determinate fixation requires a complete focus on the idea to which steep instrumentality points, within a relatively tightly circumscribed belief system. A variety of intellectual approaches within the larger framework of Critical Theory would tend to point away from determinate fixation, but only to the extent that those committed to various strands of neo-Marxist philosophy can avoid a commitment to liberating tolerance. In other words, the repression of potentially incorrect beliefs tends towards determinate fixation even if the broader philosophical framework of Critical Theory does not require it.

Blacker is careful to note that the charge of fanaticism should not be leveled lightly, should not be used as a shortcut for censoring particular beliefs, and should be a difficult case to prove. The burden of proof is on the accuser. A key point is that, in avoiding fanaticism, individuals should be allowed to "to deliberate rationally among competing conceptions of the good life." Marcuse rejects this value by closing the community of conversation to those whom he deigns sufficiently regressive. The result is a loss of contingency, denying others the agency to define their lives and values according to divergent or even traditional criteria. Using the term "fanaticism" in relationship to Marcuse may be shocking at first glance. After all, the fanatic conjures an image of the irrational partisan often acting in service of socially marginal causes. It is important to note, however, that fanaticism is not necessarily irrational, and need not be directed towards unjust ends. The danger in fanaticism instead resides in its impulse to totalize social phenomena without maintaining a fallible stance. From this perspective, my classification of Marcuse's approach as fanatical follows from extant criticisms of Repressive Tolerance as noted above. ${ }^{2}$ Supporters of Marcuse's essay have not addressed these criticisms directly, tending to situate Marcuse's argument as a response to systematic intolerance (Fopp 2007) or particular historical situations (Kellner 2006). Scholars in the field of education have tended to focus on the utility of repressive tolerance as an explanatory mechanism for systematic intolerance within democratic societies, rather than engaging liberating tolerance directly (Brookfield 2007; Schmidt

Perrine, William M. 2017. The perils of repressive tolerance in music education curriculum. Action, Criticism, and Theory for Music Education 16 (2): 6-38. doi:10.22176/act16.2.6 
2007). That repressive tolerance (if it exists) can function to mask social oppression, however, is not in question. More pertinent questions include whether this is the only function such tolerance can have, and whether liberating tolerance is the appropriate response to the problems that recognition of repressive tolerance might reveal.

\section{Liberating Tolerance and Critical Pedagogy}

Critical Theory entered the realm of education and curriculum theory through what Pinar, Reynolds, Slattery, and Taubman (2008) have called the "re-conceptualization" of the field during the 1970s. This movement rejected the traditional value of academic neutrality, arguing that neutrality itself is an ideological position requiring an even playing field that does not exist. Drawing both from Critical Theory and post-structuralism, it sought to transform society through the deconstruction and transformation of educational practice. Spearheaded by scholars such as Michael Apple, Henry Giroux, and Peter McLaren, this movement included a Marxist social critique mirroring Marcuse's (1972) dictum that "All authentic education is political education," advocating engagement in resistance and radical intervention. ${ }^{3}$ Rejecting the traditional role of the curriculum specialist in the academy and in public education, these scholars sought a more politically active curriculum in pursuit of their vision of social justice. In the field of curriculum, Critical Theory remains a significant tool in addressing social and economic inequities perpetuated by the structures of the public education system. Claims regarding totalities and universals with school curricula are subject to the process of deconstruction. Proponents of this approach view a confluence of commercial and conservative political forces within a capitalist framework as preventing the implementation of progressive alternatives.

The work of Paulo Freire, profoundly significant in the reconceptualization of the curriculum field, contains significant overlap with Marcuse's discussion in Repressive Tolerance that merits discussion at this point. Like Marcuse, Freire (1970) embraced a political approach to education situated within a view of society divided into the oppressed and the oppressors. His liberatory education is a fundamentally political approach, with the stated aim of enabling students to achieve a total view of reality and its causes. For Freire, critical thinking develops through a

Perrine, William M. 2017. The perils of repressive tolerance in music education curriculum. Action, Criticism, and Theory for Music Education 16 (2): 6-38. doi:10.22176/act16.2.6 
process of dialog between teacher and students. Education is not complete, however, unless an enhanced perception of reality is accompanied by action geared towards revolutionary action aimed at breaking down the power of the oppressive class. The purpose of dialog in bringing about liberation is gaining adherence to the revolution by the people, which includes a common set of assumptions regarding reality that is to be embraced as a whole. Scholars such as Ira Shor were instrumental in importing Freire's work into an American cultural context. Shor (1992), explicitly following Freire, argued that schooling should empower students to engage in social change through a critical democratic pedagogy that will liberate students from the antidemocratic and orthodox thinking bred by traditional pedagogical approaches. Like Marcuse, Freire makes a case that certain ideas must be repressed in order to further the cause of liberation. He called for the repression of those voices who refuse to be re-educated following the revolution; in fact, he argued that liberating revolutionaries have an ethical responsibility to do so to avoid regression into oppressive power structures. Also, in a similar vein to Marcuse, Freire excuses violence by the oppressed classes; after all, a failure to embrace liberation stems from either a hatred of life, a fear of freedom, or ignorance. 4

The philosophical overlap between Marcuse and Freire points to the manner in which liberating tolerance currently functions within various academic disciplines. Both Marcuse and Freire drew on Marxist humanism as a conceptual framework, and it is unsurprising to note convergent streams of argumentation. Other scholars, engaged in both Critical Theory and Pedagogy, work within the same philosophical outlook, one that Lukács (1972) appropriately described as an "unconditional hegemony of the totality." On a deep level, liberating tolerance is the logical end of totalizing theory appearing in various strands of neo-Marxist thought, regardless of whether the authors in question explicitly reference Marcuse's work. Ellis (2002) notes that contemporary intolerance in academic circles towards "incorrect" opinions representing the perceived status quo has its roots in interpretations of Marx produced by Lenin and Mao, both of whom Freire references approvingly in Pedagogy of the Oppressed. Of particular importance is the distinction between pravda, truth that furthers social justice, and istina, the empirical state of affairs. The distinction finds echoes in Marcuse's (1941) advocacy of social theory as opposed to empirical positivism, or Habermas's (1981) contrast

Perrine, William M. 2017. The perils of repressive tolerance in music education curriculum. Action, Criticism, and Theory for Music Education 16 (2): 6-38. doi:10.22176/act16.2.6 
between communicative and instrumental rationality. In this light, Marcuse's liberating tolerance is not so much a new idea as it is a formalization of the consistent outcome of views on the nature of truth found in various strands of Marxist humanism. The actualization of these ideas within academic discourse, then, can be linked conceptually to Marcuse even when the practitioners themselves do not make an explicit connection.

In examining academic literature for examples of liberating tolerance, one would thus not expect to see overt references to the concept. As argued by Marcuse, within an educational context liberating tolerance is a self-imposed approach by faculty and students. It is possible that for the individual with a dialectical personality, predisposed to the resentment towards capitalism common in academia (Cushman 2012), the application of liberating tolerance may be a reflexive philosophical move rather than an intentional one. A scholar may never use the term "liberating tolerance," or even demonstrate familiarity with Marcuse's work, yet engage in discriminating tolerance towards the political Right. Practically, then, liberating tolerance can only be recognized symptomatically, in the same manner as repressive tolerance: via its impact on potential discourse and action. Symptoms of liberating tolerance include general suppression of the views of the political right, the removal of the possibility of dissent from leftist orthodoxy to an evershrinking private sphere, the moralization and personalization of political discourse, and the reduction of non-liberatory ideas to merely formal or illegitimate positions. Within this context, Blacker's conceptual framework for understanding fanaticism can be useful in identifying the ways in which the impulse towards liberating tolerance plays out within academic literature. The warning signs of liberating tolerance in action are a comprehensive philosophy centered in neo-Marxist or Marxist humanist thought, situated within but not limited to critical intellectual traditions, combined with a single-minded political approach grounded in critiques of capitalism and its attendant social institutions.

\section{Liberating Tolerance and Music Education}

While scholarly inquiry drawing from Critical Theory and Pedagogy entered music education later than the field of curriculum theory in general, much of our current philosophical discussion draws from its conceptual framework. The dominance of

Perrine, William M. 2017. The perils of repressive tolerance in music education curriculum. Action, Criticism, and Theory for Music Education 16 (2): 6-38. doi:10.22176/act16.2.6 
an aesthetic understanding of music education in the mid-20 ${ }^{\text {th }}$ century relied heavily on analytic philosophy. It was perhaps inevitable that a broader move away from analytic philosophy in the academy would lead scholars to examine and incorporate critical insights in the music curriculum. David Elliott's praxial approach in Music Matters (1995) certainly opened doors for Critical Pedagogy by recasting music as a human activity rather than as an object or artifact to be studied and reproduced. If music is a human activity, toward what ends is that activity directed? How does the human activity of music function in a broader social context of other human activities? These questions have been taken up by the MayDay Group, a self-described "international think tank" dedicated towards challenging and transforming traditional music education curriculum and educational policies. A primary purpose of the Group is to apply Critical Theory "to the purposes and practices of music education." The name of the group itself points in part to a celebration of revolutionary political values. The Group's stated aims advocate tying theory to action, including an emphasis on viewing music education researchers and practitioners as agents of social change.

To what ends is this social change directed? The stated purposes of the MayDay Group suggest that this social change has a particular trajectory, toward a particular set of liberatory values. The emphasis on music teachers as active agents of social change, with attendant concerns over identity construction and social justice, has a specific political bent. While various arguments offered by members of the Group may demonstrate a variety of approaches, emphasis, and solutions, a core orthodoxy of liberating praxis retains significant correspondence with the values of Marxist humanism espoused by Marcuse, Freire, and others. In one sense, this is not problematic in and of itself. There is no reason why an academic should not approach any given philosophical problem with pre-existing ideological commitments. In fact, it may be humanly impossible to avoid doing so. Further, a great deal of research conducted from this perspective is of high quality, yielding significant insights into the human condition. On the other hand, to the extent that scholarship embraces an ideology that demands both comprehensiveness and single-mindedness in its core value commitments, politicization entails real perils for music education. These perils are symptomatic of a liberating tolerance that fails to appreciate heterodox intellectual approaches to various problems within the discipline. I will briefly address two areas of practical concern: instances in which

Perrine, William M. 2017. The perils of repressive tolerance in music education curriculum. Action, Criticism, and Theory for Music Education 16 (2): 6-38. doi:10.22176/act16.2.6 
perspectives laying outside progressive political orthodoxy have been misrepresented, and an example of how Leftist ideology has unnecessarily politicized existing music education practice.

As has been noted, Critical Theory is a comprehensive philosophical approach. This does not mean an absence of diversity of thought or rigorous debate, but rather a shared framework for understanding the nature of reality. Within music education, various themes emerge when discussing music education from a critical perspective: a critique of capitalism as an economic system and its disparate impact on musical opportunity for children; concern regarding neoliberal political policies which tend to devalue music and the arts as a curricular area; the negative influence on large corporations on mass culture and students' musical horizons; and a concern for minority and disadvantaged students and their musical values. Discussion of any of these concerns should not be exclusively limited to a framework grounded in any left-leaning philosophy. Unfortunately, there are few examples of conservative inquiry into these matters in music education, mirroring intellectual gaps in the social sciences and humanities more generally (Hayward 2014; Shields and Dunn 2016). Further, when conservative or libertarian ideas are presented, the discussion often demonstrates little understanding of alternative intellectual traditions on their own terms, as will be discussed below. While the caricature of dissenting opinion does a disservice to the opposition, it can also be viewed as an actualization of Marcuse's liberating tolerance, in which competing positions only exist in a formal sense. The obvious problem with a closed discussion was neatly summed up by Mill (1859):

He who knows only his own side of the case knows little of that. His reasons may be good, and no one may be able to refute them. But if he is equally unable to refute the reasons on the opposite side, if he does not so much as know what they are, he has no ground for preferring either opinion.

The opposite of a single-minded approach, then, is a willingness to consider alternate points of view. Liberating tolerance denies individuals the agency to do so, by reducing opposition to a formal (and often immoral) position. Integrity necessitates acknowledging and allowing the possibility of real dissent, and considering alternatives. As scholars, we should strive to present the ideas of our opponents on their own terms, even if we must inevitably respond on our own.

Perrine, William M. 2017. The perils of repressive tolerance in music education curriculum. Action, Criticism, and Theory for Music Education 16 (2): 6-38. doi:10.22176/act16.2.6 
The clearest instances to be drawn from philosophical literature in music education can be found when scholars directly engage in political discussion. Before examining specifics, it is important to note that these examples have been selected as representative instances of misconstruing divergent viewpoints. These examples are not meant to be a comprehensive review of the problem, a suggestion that these authors have expressed uniform political commitments, or an insinuation that any specific statements are representative of any particular author's overall views regarding music education. While in some cases these illustrations are central to an author's overall argument in a given forum, at other times they are simply incidental assumptions that shape the overall tenor of philosophical discourse within the discipline.

Paul Woodford's (2005) Democracy in Music Education provides several compelling examples. Woodford is correct to observe that the academy's ritualistic anti-capitalism precludes finding space for common ground, and is to be commended for resisting utopian thinking while critiquing an overly political and dualistic approach to education. Unfortunately, his otherwise humane appeal for pure tolerance is undercut by the tenor and content of his political critique, specifically in reference to what we might term the "corporate narrative" of American education. This begins with a broad overgeneralization of the "New Right," a coalition of purportedly regressive and authoritarian interests serving the function of a useful antagonist. The subsequent narrative is remarkably predictable and conformist with left-of-center narratives, reducing the discourse to talking points. The New Right desires a return to social authoritarianism, and conservatives are plotting to defund and destroy public education. Conservatives do not believe in egalitarianism, do not recognize the need to provide equality of opportunity for students, and advocate policies rooted in Social Darwinism. This agenda is driven by racism and classism, with the ultimate aim of returning to an autocratic society in which poorly educated consumers are unmoved by concerns for equity or justice:

The New Right's move...is really part of a much larger, and hidden, political agenda that may well be both racist and classist and thus inimical to democracy. The real aim of the New Right is to return to a more autocratic, ordered, and structured society controlled by corporate greed. Thus the New Right's interest in controlling the educational system. (Woodford 2005, 65)

This, of course, is a caricature of the opposition. 5 While it is outside the scope of this paper to present a counter-narrative, I would argue that this approach 
demonstrates a lack of understanding of the relationship between conservative and libertarian ideas on education to the corporate narrative, or where the very real fracture points lie in the ostensibly monolithic "New Right." No real space for alternatives exists within the narrative, as the hope for common ground would seem to necessitate accepting the contours of the problem as defined. In other instances, Woodford $(2008,113)$ conflates utilitarianism and an overly simplistic definition of conservativism, arguing that "the current utilitarian agenda for higher education is by definition conservative: There is little appreciation of complexity or for anything that is controversial and not of immediate commercial value." This approach lacks a nuanced understanding of how utilitarianism and social efficiency infect policies on both sides of the left/right political divide. Implying that moderates are more capable of skepticism than the Right (Woodford 2008, 108), or that the Right is motivated by hatred (Woodford 2008, 109), are accusations that cannot be substantiated empirically but serve to reduce dissent to a merely formal position in a Marcusean sense. Similarly, Woodford $(2014,26)$ argues that conservatives and the religious right resist critical thinking in opposing progressive pedagogical approaches, but this is ungenerous. Perhaps conservatives are simply engaging in critical thinking against the Left, even though from the standpoint of neo-Marxist doctrine this must be an indication of false consciousness.

Michael Apple's (2003) contribution to music education scholarship, in presenting the standard corporate narrative of education, is remarkably similar to Woodford in both its line of reasoning and its treatment of conservative positions as illegitimate. Intriguingly, Apple worries about a delegitimization of dissent from the political Right that would deny the possibility of progressive alternatives when he notes that "These [discursive] strategies ... involve not only presenting one's opinions as commonsense, but also usually tacitly implying that there is something of a conspiracy among one's opponents to deny the truth" (Apple 2003, 7). From the context, however, Apple is not arguing for a free marketplace of ideas in which various factions (including those on the Right) can negotiate and compromise. Rather, his concern is another way of expressing Marcuse's problem of repressive tolerance, arguing that the political stranglehold of the Right precludes liberatory action. Apple is also prone to misrepresent divergent viewpoints in a manner consistent with liberating tolerance. His treatment of E. D. Hirsch is a case in point. ${ }^{6}$ In my reading of Hirsch, there is nothing to suggest a link to the type of neo-liberal,

Perrine, William M. 2017. The perils of repressive tolerance in music education curriculum. Action, Criticism, and Theory for Music Education 16 (2): 6-38. doi:10.22176/act16.2.6 
market driven reforms that Apple suggests. In fact, Hirsch (2009) presents a reasonably balanced view of the charter school movement and the problems of approaching education in purely economic terms. Further, he refuses to self-identify as a conservative and cites Gramsci as a primary influence on his curricular philosophy. The fact that conservatives have found value in various aspects of Hirsch's work points not to a lack of critical thought, but rather towards a radically different view of politics than one would find on the far Left. Here we see a resistance to totalizing approaches, and a practical embrace of potentially beneficial ideas from wherever they might be found. The result is a politics of compromise and pragmatism rather than one directed towards idealistic or utopian social ends.

Alternate approaches to curriculum theory are also commonly misunderstood. In his discussion of Paul Woodford's Democracy in Music Education, David Elliott (2008) reiterates his criticism of classical liberalism originally presented in Music Matters, in which he argues that "the focus of many efforts in liberal education has become rather self-indulgent and, therefore, developmentally limited. A truly developmental education cannot afford such a selfish focus" (Elliott 1995, 307). Elliott's criticism is drawn from Dewey (1916), whom he quotes:

There is a standing danger that the material of formal instruction will be merely the subject matter of the schools, isolated from the subject matter of life-experience. Thus we reach the ordinary notion of education: the notion which ignores its social necessity and its identity with all human association that affects conscious life, and which identifies it with imparting information about remote matters and the conveying of learning through verbal signs: the acquisition of literacy. (9-10)

As a proponent of classical liberalism, and of the necessity of a broad liberal arts education that includes music at both the elementary and secondary level, I find that Elliott's criticism of this approach as the "ordinary notion of education" (Elliott 2008, 48) bears only a passing resemblance to the actual tenants of said beliefs. I am unaware of any proponents of classical liberalism that view formal knowledge as fundamentally disconnected from social necessity; claims to the contrary invariably appeal to a hidden rather than expressed agenda. The problem, however, does not rest in Elliott's case, but rather in Dewey's. As is characteristic of his work, Dewey repeatedly inveighs against "ordinary" or "traditional" education for polemic purposes. His critiques are a straw man argument, casting his opponents in the worst possible light as inherently unreasonable.7 Dewey also is a

Perrine, William M. 2017. The perils of repressive tolerance in music education curriculum. Action, Criticism, and Theory for Music Education 16 (2): 6-38. doi:10.22176/act16.2.6 
pioneer in the use of language to delegitimize dissent, presaging Marcuse's discussion of tolerance by several decades. After all, who could seriously argue against growth or a child-centered approach, except in a formal sense? Dewey's repeated injunctions against traditional education have thus attained the status of dogma. In a similar vein, Allsup's $(2010,224)$ discussion of traditional approaches to curriculum makes similar errors. After incorrectly defining essentialists as "those scholars who wish to protect a singular view of the truth," he constructs a convenient but misleading syllogism:

All education involves a search for truth.

All truth is universal.

Therefore, one universal course of study should apply to all students everywhere.

While the second condition is likely the most problematic for Allsup, the overgeneralized conclusion misrepresents essentialist thought, at least in terms of the scholars he is citing. Specifically, his labeling of Anthony Kronman as a "conservative" (or even an "essentialist") within this context is confounding. Kronman (2007), a self-identified liberal Democrat, makes the case for the importance of a classical liberal arts education without engaging in reductionism. Perhaps "conservative" in this case is merely a signifier that Kronman has stepped outside the acceptable boundaries of critical orthodoxy, and is a quick way to discredit his viewpoint.

A more strident example is found in Peter McLaren's recent discussion of music education for social justice. McLaren (2011) is critical of both the establishment right and left in American politics. He argues that both poles of the political spectrum inhibit social progress via the vigorous protection of special interests, and that critical music educators should engage in resistance through radical negativity. What is intriguing in this article is the way in which McLaren's language points toward determinate fixation: life is merely endured as all facets of existence contribute to a profound reality of alienation. Only a select few (Chomsky, Nader, and most likely McLaren himself) have the moral autonomy to speak truth to the system. The common folk on the Right are, most charitably, simply duped by the Koch brothers; alternately they are a lunatic fringe or the "prehensile tale of libertarianism" $[$ sic $]$ lurching towards fascism:

Ironically, those well-intentioned members of the Tea Party who believe they are fighting elite power as part of a grassroots movement, fail to recognize that they

Perrine, William M. 2017. The perils of repressive tolerance in music education curriculum. Action, Criticism, and Theory for Music Education 16 (2): 6-38. doi:10.22176/act16.2.6 
have been duped by billionaires-in particular, the Koch brothers-to serve as ideological handmaidens of their ideological dirty work.... Under the apparent benignity of the Tea Bag party's conception of democracy lurks a hideous, reckless revisionism. (McLaren 2011, 132)

Using an explicitly derogatory metaphor ("Tea Bag”) to dismiss one's opponents is a textbook example of Blacker's fanaticism in action. Perhaps McClaren can successfully employ such language due to his stature as a scholar, but this type of slur comes closer to hateful invective than it does to a reasoned argument.

One could argue that McLaren's approach is an outlier. Yet I am concerned that the overwhelming narrative presented in curricular discourse paints a picture of liberating tolerance successfully implemented, and thus undetected. The correct political view is assumed, often in moral or highly charged language, constructing a core orthodoxy that discourages critique on terms other than its own. Further examples drawn from the literature illustrate the point. Allsup (2009) presents a dystopian view of American culture, fraught with unsupported assumptions regarding neo-liberalist capitalism. Most striking in his argument is the assertion that "authentic consciousness" is a precondition for constructing meaning in a society soaked in veiled symbols of unconscious ideology (Allsup 2009, 36). How does one demonstrate authentic consciousness, except by the public profession of the correct political perspectives? At this point, dissent loses footing in potential dialog regarding the interpretation of cultural symbols and metaphors, as it can easily be categorized as ideology or false consciousness. Gould $(2008,40)$ advocates utter contempt for liberal democracy due to its perceived flaws, as "democratic institutions, and so-called democratic practices based on dualistic structures and thinking that not only enable, but necessitate assimilation and domination." Are the citizens who love liberal democracy (or perhaps more accurately, representative democracy as a political system) and work willingly to uphold its social structures also worthy of contempt? The social control of citizens via assimilation that underlies democratic systems is another way of articulating Marcuse's repressive tolerance (Gould 2008, 31). Gould $(2008,36)$ further argues that university professors, as delegated agents of the state, perpetuate symbolic violence on students unless they can decolonize their views. Grimmett $(2014,9)$ agrees, worrying that neo-liberalism undermines professionalism by making teachers the servants of the state: "neo-liberalist pressures ... attempt to re-professionalize teachers as

Perrine, William M. 2017. The perils of repressive tolerance in music education curriculum. Action, Criticism, and Theory for Music Education 16 (2): 6-38. doi:10.22176/act16.2.6 
'servants of the state' merely carrying out public policy, that is, where professionalism is arrogated to the uncritical carrying out of government policy." One wonders when publicly funded teachers or professors have not been state employees, given who pays their salaries, why such employees should not be accountable to said taxpayers in some form, and what the alternative might be. Similarly, Schmidt $(2008,16)$ notes that the democratic value of mutual understanding and respect can, in fact, be a matter of enacted colonialism. Schmidt $(2012,156)$ references Marcuse and repressive tolerance directly, arguing that while our pedagogical approaches purport to generate empowered students they in fact do the opposite. His alternative is conversation rather than absolute truth, although there is no evidence to suggest a lack of conversation or even vigorous debate prior to the epistemological shifts that placed absolute truth or Natural Law in academic disrepute. Williams $(2015,30)$ again argues that Critical Pedagogy, by its nature, is "inherently antagonistic to authoritarianism." Is this an either/or situation, however? There is a strong streak of anti-authoritarianism in both conservative and libertarian thought that cannot be reduced via liberating tolerance to a "neocolonial apparatus."

Ideological research of this type has direct implications for traditional music education curriculum and practice. This approach can generate partisan controversy regarding traditional practices that fails to capture the inherent complexity of the institutions under critique. In particular, I would like to briefly examine the critique of the large ensemble experience that has been central to American secondary music education for a century. If the purpose of education is to foster liberatory action geared towards social transformation, it is not difficult to see how institutions that appear to preserve existing social structures would come under intense scrutiny. The wind band in particular, perhaps because of its social prominence in connection with school athletics, has been the recipient of concentrated criticism. As a band director myself, I have often noted tension in the often frustrated or alienated reactions of colleagues in the College Band Directors National Association (CBDNA) to critical discussions of the large ensemble. My purpose at this time is not to respond directly to flawed arguments regarding the problematic nature of the large instrumental ensemble, but rather to observe the ways in which the language of critique serves to moralize and limit the discourse. The narrative

Perrine, William M. 2017. The perils of repressive tolerance in music education curriculum. Action, Criticism, and Theory for Music Education 16 (2): 6-38. doi:10.22176/act16.2.6 
generated, in placing traditional approaches on the "wrong" side in the context of democratic education, limits space for dissent by evoking liberating tolerance.

Many collegiate band directors, for example, might acknowledge the influence of aesthetic philosophy on the development of CBNDA as an organization (Maiello 2013). Yet they would be rightly puzzled by arguments suggesting that a heritage grounded in aesthetic theory has unwittingly pushed the country towards the political right, or that discussions of "great music" can be linked to efforts by capitalists and the military industrial complex to stifle dissent and maintain political power. This is the argument offered by Woodford (2014):

the persistent insularity and narrowness of many school music programs and practices ... can be traced to early Cold War politics ... and a culture of fear that created the right conditions for the rise of the aesthetic education movement, which was itself implicated in those politics insomuch as it was ideologically driven, albeit even if only indirectly, by politicians wishing to move the country further to the political right. (27)

Woodford further states "the language of aesthetic ideas of musical beauty, greatness, and profundity that in the nineteenth century contributed to the development of German notions of racial and cultural superiority, eventually culminating in the rise of the Nazi party" (Woodford 2014, 32). Certainly, rhetoric grounded in aesthetic theory regarding "great music" remains prevalent in the world of the wind band. Does it necessarily follow, though, that a conservative approach to aesthetics translates into support for conservative politics, or is this a false equivalency used to score political points against traditional ensembles? I find it rather unlikely that aesthetic ideas naturally contribute to support for National Socialism, even if a correlation can be extrapolated from German politics in the late $19^{\text {th }}$ and early $20^{\text {th }}$ centuries. Why interject the Nazis into contemporary discussions of traditional ensembles unless the purpose is to moralize the discourse? It is likely a safe assumption that a large percentage of college band directors, similar to other disciplines in the academy, leans left politically and would view their work and view of aesthetics critically in light of their existing political commitments.

Framing the relationship between the conductor and large ensemble as socially regressive has become a common topic in music education research. John Kratus (2007), for example, has described the traditional large ensemble as an autocratic institution:

Perrine, William M. 2017. The perils of repressive tolerance in music education curriculum. Action, Criticism, and Theory for Music Education 16 (2): 6-38. doi:10.22176/act16.2.6 
In many cases, the ensemble director selects all the music, makes all the artistic decisions regarding interpretation, and shapes the resulting performance through tightly managed rehearsals to match a preconceived notion of the piece, correcting errors along the way. It is an autocratic model that has no parallel in any other subject. (46)

In terms of language, the problem in the argument is not that Kratus argues for what he considers student-centered approaches, but rather that he has positioned the large ensemble as no longer being "personally fulfilling and educationally valid." Elsewhere, he has characterized traditional bands and choirs that utilize auditions for acceptance as autocratic, noting that "Opportunities for making music that are available only to those who have been designated as 'talented' would be antidemocratic. An example of this would be a school's music program that accepts only students who have passed an audition." (Kratus 2012, 100). Similarly, he rejects participation in traditional ensemble festivals for evaluation as anti-democratic on similar grounds: "Democratic music educators must reject all forms of standardized testing, including ensemble festivals and contests that hold all performers to the same set of standards and repertoire" (Kratus 2012, 104). Perhaps these practices are problematic, but the language places music educators that support traditional forms of music education in the position of advocating against democracy. The opportunity for robust reflection and debate is thus circumscribed.

Further examples are not difficult to find. Allsup and Benedict (2008) criticize the wind band for perpetuating a pedagogy of fear, subjugating students as directors control their artistic endeavors. Regelski (2012) similarly worries that traditional approaches utilized in building a good program place musical values above students' educational needs, an unethical mindset he describes as "musicianism." Schmidt $(2012,157)$ argues that the drive to create semi-professional ensembles at the tertiary level damages K12 music education, as secondary music teachers seek to replicate their collegiate experience and lack the ability to create alternatives. This is also framed as a matter of ethics, as traditional ensembles tend to deny students the agency to engage in the "authorship" of personal musical expression. The problem here is not that these critiques may have merit in particular cases, but rather that the authors have overgeneralized based on anecdote to generate a sweeping narrative that condemns instrumental music in large ensembles far too broadly. Informally and anecdotally, I have heard the use of language such as "dinosaurs headed towards extinction" by collegiate music educators in reference to

Perrine, William M. 2017. The perils of repressive tolerance in music education curriculum. Action, Criticism, and Theory for Music Education 16 (2): 6-38. doi:10.22176/act16.2.6 
large ensembles. From the outside, the overall narrative appears to suggest that change is not only imperative for music education, but that proponents of traditional ensemble experiences are perpetuating the hegemony of anti-democratic forces by denying space for liberatory action. While this viewpoint makes sense within academic discourse grounded in various strands of Critical Pedagogy or Marxist humanism, liberating tolerance against tradition has actually obscured a great deal of praxial pedagogical development within the wind band world of which critics appear unaware. ${ }^{8}$ I believe that this is what Mark Fonder (2014) was attempting to communicate in his broadside against "academicians" that was received warmly at the 2015 national convention of CBDNA.

\section{Whither pure tolerance?}

Is a pure tolerance possible? Consider that labels, whether "academician" or "traditionalist," often have the function of placing ideological opponents in a defensive position designed to force the discussion onto a particular ideological turf. The use of language in this way, coupled with a dismissive tone in philosophical arguments, can tend to marginalize or delegitimize dissenting views. This obviously can be a problem with all arguments, regardless of political perspective. From a practical standpoint, however, it is impossible to discuss ideas without some sort of conceptual grouping of particular ideas. The best solution is to be charitable towards divergent viewpoints, attempting to understand alternatives on their own terms. In other words, this is an argument for pure tolerance. My contention in this paper has been that liberating tolerance is fundamentally inhospitable towards this perspective. Because outlooks grounded in Critical Theory or Pedagogy are driven towards particular liberatory ends, there is a strong tendency towards comprehensiveness and single-mindedness.

I am thus doubtful that a call for a revitalized pure tolerance could have any substantial impact on the profession, or civil discourse more generally. Pure tolerance is not the natural bent of humanity. Rather, it is a learned virtue that perhaps only arises and functions within a liberal capitalist society that places a premium on individual liberty, property rights, and peaceful co-existence. ${ }^{9}$ Pure tolerance is not compatible with a neo-Marxist stance, nor is it compatible with other philosophical strands that have emerged from the work of the New Left. These are oppositional and transformational approaches that value group cohesion towards

Perrine, William M. 2017. The perils of repressive tolerance in music education curriculum. Action, Criticism, and Theory for Music Education 16 (2): 6-38. doi:10.22176/act16.2.6 
specified social goals. Heterodoxy cannot help but be regressive, particularly if the dissent dares argue for the value of free markets, normative classical liberal values, or traditional religious practices. Any appeal to pure tolerance is immediately contextualized the actualization of deep-seated prejudices in need of decolonization. Liberating tolerance becomes its own form of repressive tolerance, in which dissenters can believe what they like as long as they do not move from thought to action. Dialog with the opposition, unfortunately, is precluded at the outset by a Manichean, zero-sum game approach to politics. True conversation suggests not only fallibility and vulnerability in listening to the other, but a willingness to compromise with one's opponents. How, though, can one compromise with an oppressor without submitting to oppression? Compromise in the context of liberatory praxis is always a one-way street.

While I argue that it this is a structural feature of Critical Theories, the resulting marginalization of heterodox positions on the part of individual scholars may or may not be intentional. Certainly, most philosophers of music education would argue in the abstract for a variety of perspectives within our discipline. Bowman (2007), for example, argues that a free society requires "consensual agreement among free and equal individuals without suppression of dissent" (8; emphasis in original). Yet liberating tolerance is at work here as well. What occurs when consensual agreement is not possible among equal individuals? Arguing that freedom requires consensual agreement is nonsensical, unless one is operating within a critical framework that places a premium on group solidarity towards particular social ends. I thus argue from a different starting point: a free society does not require consensual agreement, but rather consensual tolerance.

It is interesting to note that the critical enterprise itself operates under an assumption of marginalization in relationship to the broader structure of music in the university, which tends to value traditional art forms and pedagogical approaches. This is not the only way to look at the current philosophical situation, however. The apparent marginalization of critical approaches in music education in relation to traditional curricula can also be seen as a movement by scholars to place music education under the broader umbrella of Critical Pedagogy within the field of education. Critical Pedagogy is not in a marginalized position within the broader context of academia. Instead, its philosophical framework enjoys wide-

Perrine, William M. 2017. The perils of repressive tolerance in music education curriculum. Action, Criticism, and Theory for Music Education 16 (2): 6-38. doi:10.22176/act16.2.6 
spread support throughout the humanities and social sciences to the point of becoming exclusive and self-replicating (Klein and Stern 2009). Further, there is substantial evidence that the New Left has in fact succeeded in imposing a philosophical paradigm shift on American society, and now occupies centers of elite power within American culture from which it can dictate cosmopolitan values and mores to the broader population (Rothman 2016).

While I am pessimistic about the prospects of pure tolerance within our current cultural moment, I remain an advocate of a classically liberal approach. I agree with Scruton (2015) that the answer to the problem of autonomy and alienation lies with the Enlightenment enjoinder to respect both the sovereignty of the individual and the voluntary associations that comprise society's constituent elements. In terms of education, students should be given access to the full range of thought on any particular issue. This includes real engagement with the best ideas and art from the past, respecting what Chesterton (1908) refers to as the "democracy of the dead." This is particularly imperative for today's students, who research reveals are the first generation in a half century to be less tolerant than their parents. This growing intolerance towards divergent viewpoints is coupled with an indifference towards free speech, and is correlated with an orientation towards social justice (Kelly-Woessner, 2016).

Valuing a diversity of viewpoints does not preclude a professor from expressing his or her own opinion, but simply necessitates allowing students to come to their own conclusions. On a personal level, my own thinking and view of the world has been strengthened across my educational career by having no choice but to seriously engage with viewpoints originating from the New Left. I have always hoped that my progressive friends would want the same. The idea that there are no intellectually rigorous alternatives should be rejected. This is not to say that most professors are out to indoctrinate their students, as empirical evidence suggests that this is not occurring (Shields and Dunn 2016). Rather, a monolithic or comprehensive approach can lead to self-selection bias, blind spots, and group think within the academic community (Klein and Stern 2009). This might require more efforts on the part of conscientious professors, as many disciplines in the academy are so dominated by the descendants of the New Left that alternate viewpoints may not be readily accessible or directly applicable. However, cross-disciplinary work bringing in sources from political science, sociology, law, or economics can help

Perrine, William M. 2017. The perils of repressive tolerance in music education curriculum. Action, Criticism, and Theory for Music Education 16 (2): 6-38. doi:10.22176/act16.2.6 
shed light on both alternative and traditional approaches within the discipline of music education.

In closing, I would like to share a final appeal for pure tolerance from Ludwig van Mises (1927), one of the founders of the Austrian school of economics:

For what impels liberalism to demand and accord toleration is not consideration for the content of the doctrine to be tolerated, but the knowledge that only tolerance can create and preserve the condition of social peace without which humanity must relapse into the barbarism and penury of centuries long past. (56)

Tolerance, like civilization itself, is a more fragile social construct that many would care to admit. Once lost, it is not easily restored or rebuilt. I would urge my more progressive colleagues to at least exercise caution on this front in their zeal for liberating action and transformational societal change.

\section{About the Author}

Dr. William Perrine is an Assistant Professor of Music and Department Chair at Concordia University Ann Arbor in Ann Arbor, Michigan. He directs the wind and string ensembles, and teaches a variety of courses in music and education. Dr. Perrine is a National Board Certified Teacher, and has 10 years of public school teaching experience, primarily in Title I schools in Florida and Kentucky. He holds a $\mathrm{PhD}$ in Music Education from Indiana University, and a master's degree in Wind Conducting from the University of Nebraska-Lincoln. He can be reached at william.perrine@cuaa.edu.

\section{References}

Allsup, Randall Everett, and Cathy Benedict. 2008. The problems of band: An inquiry into the future of instrumental music education. Philosophy of Music Education Review 16 (2): 156-73.

Allsup, Randall Everett. 2009. Rough play: Music and symbolic violence in an age of perpetual war. Action, Criticism, and Theory for Music Education 8 (1): 3553 .

Allsup, Randall Everett. 2010. Choosing musical literature. In Critical issues in music education: Contemporary theory and practice, edited by Harold F. Abeles and Lori A. Custodero, 39-60. New York: Oxford University Press.

Perrine, William M. 2017. The perils of repressive tolerance in music education curriculum. Action, Criticism, and Theory for Music Education 16 (2): 6-38. doi:10.22176/act16.2.6 
Apple, Michael W. 2003. Competition, knowledge, and the loss of educational vision. Philosophy of Music Education Review 11 (1): 3-22.

Blacker, David. 1998. Fanaticism and schooling in the democratic state. American Journal of Education 106 (2): 241-72.

Bowman, Wayne. 2007. Who's asking (Who's answering)? Theorizing social justice in music education. Action, Criticism, and Theory for Music Education 6 (4): $1-20$.

Brookfield, Stephen. 2007. Diversifying curriculum as the practice of repressive tolerance. Teaching in Higher Education 12 (5-6): 557-68.

Chesterton, G. K. 1908/1995. Orthodoxy. San Francisco: Ignatius Press.

Cushman, Thomas. 2012. Intellectuals and resentment toward capitalism. Society 49 (3): $247-55$.

DeVitis, Joseph L. 1974. Marcuse on education: Social critique and social control. Educational Theory 24: 259-68.

Dewey, John. 1916. Democracy and education. New York: MacMillan.

Elliott, David J. 1995. Music matters: A new philosophy of music education. New York: Oxford University Press.

Elliott, David J. 2008. Music for citizenship: A commentary on Paul Woodford's Democracy and music education: Liberalism, ethics, and the politics of practice. Action, Criticism, and Theory for Music Education 7 (1): 45-73.

Ellis, Frank. 2002. Political correctness and the ideological struggle: From Lenin and Mao to Marcuse and Foucault. The Journal of Social, Political, and Economic Studies 27 (4): 409-44.

Fonder, Mark. 2014. No default necessary: Large ensembles enrich many. Music Educators Journal 101 (2): 89.

Freire, Paulo. 1970. Pedagogy of the oppressed. New York: Bloomsbury Academic.

Fopp, Rodney. 2007. Herbert Marcuse's 'repressive tolerance' and his critics. Borderlands 6 (1).

Perrine, William M. 2017. The perils of repressive tolerance in music education curriculum. Action, Criticism, and Theory for Music Education 16 (2): 6-38. doi:10.22176/act16.2.6 
Grimmett, Peter P. 2014. Mayday! Mayday! Help me if you can, I'm feeling down: "The best lack all conviction, while the worst are full of passionate intensity." Action, Criticism, and Theory for Music Education 13 (2): 5-29.

Gould, Elizabeth. 2008. Devouring the other: Democracy in music education. Action, Criticism, and Theory for Music Education 7 (1): 29-44.

Habermas, Jurgen. 1981. Theory of communicative action, Volume one: Reason and the rationalization of society. Boston, MA: Beacon Press.

Hayward, Steven F. 2014. Conservatives and higher ed. The New Criterion 32 (10).

Hirsch, E. D. 2009. The making of Americans: Democracy and our schools. New Haven, CT: Yale University Press.

Kelly-Woessner, April. 2016. The New Left and political intolerance. In The end of the experiment: The rise of cultural elites and the decline of America's civic virtue, edited by S. Rothman, 187-200. New Brunswik, NJ: Transaction Publishers.

Kellner, Douglas. 2006. Marcuse's challenges to education. Policy Futures in Education 4 (1): $1-5$.

Klein, Daniel B., and Charlotta Stern. 2009. Groupthink in Academia: Majoritarian departmental politics and the professional pyramid. The Independent Review 13 (4): 585-600.

Kors, Alan Charles, and Harvey A. Silverglate. 1999. The shadow university: The betrayal of liberty on America's campuses. New York: Harper Perennial.

Kratus, John. 2007. Music education at the tipping point. Music Educators Journal 94 (2): 42-8.

Kratus, John. 2012. Consider democracy: An ideal in music learning. In Tanglewood II: Summoning the future of music education, edited by Anthony J. Palmer and André de Quadros, 95-112. Chicago, IL: GIA Publications.

Kratus, John. 2015. The role of subversion in changing music education. In Music education: Navigating the future, edited by Clint Randles, 340-46. New York: Routledge.

Kronman, Anthony T. 2007. Education's end: Why our colleges and universities have given up on the meaning of life. New Haven, CT: Yale University Press.

Perrine, William M. 2017. The perils of repressive tolerance in music education curriculum. Action, Criticism, and Theory for Music Education 16 (2): 6-38. doi:10.22176/act16.2.6 
Lukács, Georg. 1972. Tactics and ethics: Political essays, 1919-1929. New York: Harper \& Row.

Maiello, Anthony J. 2013. The College Band Directors National Association and aesthetic education. College Music Symposium 53.

Marcuse, Herbert. 1941. Reason and revolution: Hegel and the rise of social theory. London: Routledge \& Kegan Paul, Ltd.

Marcuse, Herbert. 1965. Repressive tolerance. Boston, MA: Beacon Press.

Marcuse, Herbert. 1972. Counterrevolution and revolt. Boston, MA: Beacon Press.

Mises, Ludwig Von. 1927/1985. Liberalism: In the classical tradition. Irvington, NY: The Foundation for Economic Education.

McLaren, Peter. 2011. Radical negativity: Music education for social justice. Action, Criticism, and Theory for Music Education 10 (1): 131-47.

Mill, John Stuart. 1859/2001. On liberty. Kitchener, ON: Batoche Books Ltd.

Pinar, William F., William M. Reynolds, Patrick Slattery, and Peter M. Taubman 2008. Understanding curriculum. New York, NY: Peter Lang.

Regelski, Thomas A. 2012. Musicianism and the ethics of school music. Action, Criticism, and Theory for Music Education 11 (1): 7-42.

Rothman, Stanley. 2016. The end of the experiment: The rise of cultural elites and the decline of America's civic culture. New Brunswik, NJ: Transaction Publishers.

Scruton, Roger. 2015. Fools, frauds, and firebrands: Thinkers of the New Left. New York, NY: Bloomsbury Continuum.

Schmidt, Patrick K. 2007. In search of a reality-based community: Illusion and tolerance in music, education, and society. Philosophy of Music Education Review 15 (2): 160-7.

Schmidt, Patrick K. 2008. Democracy and dissensus: Constructing conflict in music education. Action, Criticism, and Theory for Music Education 7 (1): 10-28.

Schmidt, Patrick K. 2012. Ethics or choosing complexity in music relations. Action, Criticism, and Theory for Music Education 11 (1): 149-69.

Perrine, William M. 2017. The perils of repressive tolerance in music education curriculum. Action, Criticism, and Theory for Music Education 16 (2): 6-38. doi:10.22176/act16.2.6 
Shields, Jon A., and Joshua M. Dunn. 2016. Passing on the right: Conservative professors in the progressive university. New York: Oxford University Press.

Shor, Ira. 1992. Empowering education: Critical teaching for social change. Chicago, IL: University of Chicago Press.

Williams, Hakim Mohandas Amani. 2015. Fighting a resurgent hyper-positivism in education is music to my ears. Action, Criticism, and Theory for Music Education 14 (1): 19-43.

Woodford, Paul. 2005. Democracy and music education: Liberalism, ethics, and the politics of practice. Bloomington, IN: Indiana University Press.

Woodford, Paul. 2008. Fear and loathing in music education? Beyond democracy and music education. Action, Criticism, and Theory for Music Education 7 (1): $105-36$.

Woodford, Paul. 2014. The eclipse of the public: A Response to David Elliott's Music Education as/for Artistic Citizenship. Philosophy of Music Education Review 22 (1): 22-37.

\section{Notes}

${ }^{1}$ Writing in the 1960s, Marcuse obviously did not foresee the development of the Internet. However, even with this technological development, the quality of information to which the public has access is questionable; some evidence points to individuals on all sides of the political spectrum seeking information from sources that principally reinforce rather than challenge their existing preconceptions.

${ }^{2}$ In his literature review of scholarship critical of Repressive Tolerance, Fopp (2007) notes other strands of critique beyond Marcuse's inherent dualism and elitism. These include an inconsistent approach to liberal positions by sanctioning repression by the New Left, the support of violence in response to a violent society, and the rejection of academic neutrality.

3 See for example, Michael Apple, Official Knowledge: Democratic Education in a Conservative Age (New York NY: Routledge, 1993); Henry Giroux, Ideology, Culture, and the Process of Schooling (Philadelphia, PA: Temple University Press, 1984); Peter McClaren, Critical Pedagogy and Predatory Culture: Oppositional Politics in a Postmodern Era (New York, NY: Routledge, 1995).

4 Freire (1970) demonstrates an inability to charitably understand why individuals might dissent from his liberatory program, engaging in steep instrumentality when he describes dissenters as "necrophilius" (77). He valorizes conquest as a means of liberation (47), excuses acts of violence by Che Guevara (169) turns a blind eye to

Perrine, William M. 2017. The perils of repressive tolerance in music education curriculum. Action, Criticism, and Theory for Music Education 16 (2): 6-38. doi:10.22176/act16.2.6 
the execution of political prisoners in his valorization of dictators such as Castro (164) or Vargas (151), and holds Lenin (182) and Mao (136) in a positive light without critically examining the ends to which their respective revolutions led, namely forced labor camps, intentional famine, suppression of basic human rights, and the mass execution of dissidents.

5 I do not deny that Woodford provides a remarkable amount of annotated support for this narrative, but merely suggest that the corporate narrative is so widespread on the political Left that it is relatively easy to provide scholarly support without critically re-examining the narrative itself. Large portions of the narrative are ideological rather than empirical, and obscure a remarkable degree of overlap with conservative and libertarian concerns regarding real problems in the schools. Regardless, discriminating tolerance is in effect as the terms of discussion have been set in advance: there is no way for someone such as myself to critique the narrative, as any counter-examples can be dismissed as either ideologically biased or manifestations of false consciousness. Scholarly inquiry thus takes on the character of a merry-go-round, in which there is a single entrance and no exit.

${ }^{6}$ I would also argue that Apple's treatment of Richard Herrnstein and Charles Murray's The Bell Curve (1994) is an example of liberating tolerance. Regardless of the sins or merits of the work, Apple's throwaway reference to the book's content strikes me as more of a regurgitation of the progressive party line rather than a critical engagement or refutation of the book's actual content. Herrnstein and Murray are perhaps heretics par excellence, but it is the sociology of their treatment in academic literature, as a representative of all that is regressive in the world, that I find fascinating.

7 While Dewey purports to avoid either/or fallacies (see for example, Experience and Education. West Lafayette, IN: Kappa Delta Pi $(1938,1998): 8)$ it is interesting to note that his preference for defining education as "growth" rather than the acquisition of skills and knowledge needed for future life is an a priori philosophical commitment. No empirical evidence for the purported deleterious effects of traditional education methods, or the supposed passivity of learners in such settings, is given; the argument for progressive education is built on this assumption.

${ }^{8}$ A good example of this is John Kratus's (2015) claim that concert bands "typically perform more music from the past than the present." Most collegiate wind ensemble directors would rightly view this claim as absurd. Further, this says nothing of significant pedagogical developments in collegiate band programs that have intentionally moved away from an autocratic conducting approach.

9 I would be most happy to read an argument for an actualized pure tolerance from a critical perspective. Such an approach, however, would need to extend tolerance for both word and action to all citizens within a free marketplace of ideas. This would include proponents of capitalism as a means to alleviate poverty and ine-

Perrine, William M. 2017. The perils of repressive tolerance in music education curriculum. Action, Criticism, and Theory for Music Education 16 (2): 6-38. doi:10.22176/act16.2.6 
quality; religious fundamentalists and evangelicals whose primary concerns revolve around traditional social mores, proponents of educational choice including supporters of charter schools, neoliberals, paleo-conservatives, and libertarians. The list could go on. Dropping pretentious language such as "false consciousness" from the discourse would be a great place to begin the dialog for anyone so inclined. Treating the opposition as if they are fools or bigots is both condescending and does nothing to further real conversation or mutual understanding.

Perrine, William M. 2017. The perils of repressive tolerance in music education curriculum. Action, Criticism, and Theory for Music Education 16 (2): 6-38. doi:10.22176/act16.2.6 